\title{
Organic Fertilizing Effect of Panchagavya on Growth and Biochemical Parameters of Holy Basil (Ocimum sanctum L.)
}

\author{
Veeranan Uthirapandi ${ }^{1 *}$, Selvam Suriya ${ }^{2}$, Ponnerulan Boomibalagan ${ }^{3}$, \\ Saminathan Eswaran ${ }^{4}$, Subramanian Sivasangari Ramya ${ }^{5}$, \\ Narayanan Vijayanand ${ }^{6}$ and Durairaj Kathiresan ${ }^{7}$
}

${ }^{1}$ Centre for Research in Botany, Saraswathi Narayanan College Madurai, Tamil Nadu, India

${ }^{2}$ Research Centre in Botany, The Madura College, Madurai, Tamil Nadu, India

${ }^{3}$ Department of Botany, Pasumpon Thiru Muthuramalingam Memorial College, Kamuthi,

Tamil Nadu, India

${ }^{4}$ Department of Botany, RDM Government Arts College, Sivagangai, Tamil Nadu, India

${ }^{5}$ Department of Biochemistry, Sri Sarada Niketen College for Women, Amaravathipudur,

Tamil Nadu, India

${ }^{6}$ Department of Botany, Arumugam Pillai Seethai Ammal College, Thiruppathur,

Tamil Nadu, India

${ }^{7}$ Centre for Research in Botany, Saraswathi Narayanan College Madurai, Tamil Nadu, India

*Corresponding author

\section{A B S T R A C T}

\begin{tabular}{|l|}
\hline K e y w o r d s \\
$\begin{array}{l}\text { Panchagavya, growth, } \\
\text { Biochemical, Ocimum } \\
\text { Sanctum }\end{array}$ \\
\hline Article Info \\
\hline $\begin{array}{l}\text { Accepted: } \\
\text { 15 May 2018 } \\
\text { Available Online: } \\
\text { 10 June } 2018\end{array}$ \\
\hline
\end{tabular}

A work was conducted to identify the potential of panchagavya on growth and biochemical parameters of Ocimum Sanctum. Panchagavya were given to the tested plant in form of foliar spray. After 60 days, growth parameters such as shoot length, root length, total plant height, leaf area, number of the leaves, fresh and dried weight and biochemical parameters such as starch, glucose, protein, chlorophyll content were observed in the treated plants. Foliar application of $2 \%, 4 \%, 6 \%$ and $8 \%\left(\mathrm{~T} 1, \mathrm{~T} 2, \mathrm{~T} 3\right.$ and $\mathrm{T}_{4}$ ) enhanced the overall growth and physiology of Ocimum Sanctum. But, there was an appreciable increase in growth and biochemical parameters in the treated plants that received $8 \%$ (T4) when compared to other treatment and control. This might may be due to synergistic and cumulative effect of qualitative and quantitative active ingredients such as micro and macro elements, vitamins and phytohormones present in the Panchagavya. Thus, Panchagavya could serve as an promising effective organic biostumulant to replace the synthetic fertilizers for sustainable agriculture.

\section{Introduction}

Based on the literature and repots world population is increasing by an estimated 97 million per year (Saravi et al., 2011).
Medicinal and aromatic plants use by $80 \%$ of global population for their medicinal therapeutic effects as reported by WHO. It has been estimated that India has 47,000 species of plants. Out of these medicinal plants 
comprise 8,000 species (Rajat Rashmi, 2002). As per WHO estimates, traditional medicines, mostly plant drugs, cater to the health needs of nearly $80 \%$ of world population. Out of 4.22 lakes plants species documented worldwide, about $12.5 \%$ are reported to have medicinal or other comparable values (Rao et al., 2004). But only a few hundred were known to be in cultivation, whereas majority is collected from natural habitats. India exploited about 1400 tonnes of plant products during 2000-2001 (Anonymous, 2001). The Green Revolution is one of the biggest revolutions in history of agriculture result in increasing agricultural yield mainly in developing world. It involves investment in research, technology transfer during 1930s to late 1960 (Hazell, 2009).

The initiatives has been planned to achieve in association with agro-chemical as fertilizer and biocontrol, regulated irrigation and new methods of cultivation (Farmer, 1986). Application of chemical inputs especially chemical fertilizers, plowing and monocropping are some common agricultural activities which results in declined soil productivity, an imbalance in soil nutrients, and long-term decreasing crop yields (Khodaei et al., 2012). Panchagavya contains several nutrients i.e. macronutrients like nitrogen, phosphorus, potassium and micronutrients which are required for the growth and development of plants and also contains various amino acids, vitamins, growth regulators like Auxins, Gibberellins and also beneficial microorganisms like pseudomonas, azatobacter and phosphor bacteria etc.

Effective Micro Organisms (EMO) in panchagavya are the mixed culture of naturallyoccurring, beneficial microbes' mostly lactic acid bacteria (Lactobacillus), yeast (Saccharomyces), photosynthetic bacteria (Rhodo psuedomonas) and certain fungi (Aspergillus) (Swaminathan et al.,
2007). Yadav \& lourduraj (2006) observed bio fertilizers such as Azospirillum, Azotobactor, Phosphobacteria and Panchagavya is a foliar nutrition prepared by organic growers of Tamil Nadu and used widely for various agricultural and horticultural crops.

\section{Materials and Methods}

\section{Requirements of ingredients added for the preparation of Panchagavya}

Fresh cow's dung - 3kg

Fresh cow's urine - 5L

Cow's milk - 1L

Cow's curd - 1L

Cow's ghee - 500mg

Tender coconut water - $2 \mathrm{~L}$

Sugarcane juice - 1L

Well Ripe banana fruit - 5

Water - 5L

\section{Mode of Preparation}

Panchagavya liquid fertilizer was prepared according to method of Selvaraj et al., (2006). After 30 days the panchagavya which was filtered properly sieving through a fine cloth. The filtrates was kept as 100\% stock of panchagavya and 2 to $8 \%$ solution was prepared with mixing of appropriate distilled water and used for further treatment.

\section{Elemental composition and hormone analyses of SLE}

The composition of elements such as copper, manganese, iron, zinc, cobalt, potassium, magnesium and sodium were estimated using ICP-MS method (B'Hymer et al., 2000). Similarly, estimation of nitrogen was done as per Kjeldahl Method (Bremmer, 1960). In addition, liquid extracts were subjected for estimation of auxin (Gordon and Paleg, 1957) gibberellin (Graham and Henderson, 1961) and cytokinin (Syono and Torrey, 1976). 


\section{Selected medicinal plant}

Viable seeds of Ocimum sanctum were procured from seed storage bank of Agriculture College Madurai, Tamil Nadu. Healthy seeds free from visible infection, with uniform size were segregated. They were surface sterilized with $0.1 \%$ mercuric chloride and then sown in earthen ware pots $(9 \mathrm{~cm} \mathrm{dia)}$ filled with sterilized standard soil mix supplemented with sufficient quantity of NPK. The seed to seed distance in pot was maintained as $4 \mathrm{~cm}$ and the pots were irrigated regularly.

After 30 days of germination, different percentage of panchagavya were given in the form of foliar spray to potted plants. Separate set of potted plants were used for percentage of panchagavya.

The potted plants received $50 \mathrm{ml}$ of panchagavya $2 \%\left(\mathrm{~T}_{1}\right), 4 \%\left(\mathrm{~T}_{2}\right), 6 \%\left(\mathrm{~T}_{3}\right)$ and $8 \%\left(\mathrm{~T}_{4}\right)$ as foliar spray. The pachagavya were given at interval of 5 days for a period of 60 days. Growth parameters viz., shoot and root length, total plant height, leaf area, number of leaves and branch, fresh a dry weight of whole plant and biochemical parameters such as starch (Rose et al., 1991), glucose (Nelson, 1944), protein (Lowry et al., 1951), chlorophyll a, b and total (Arnon, 1949) were observed.

\section{Results and Discussion}

Elemental Composition and hormonal analyze of panchagavya

The panchagavya exhibited highest amount of macro and minor nutrients such as Nitrogen, Potassium, Magnesium, sodium, Iron, Molybdenum. This was followed, highest amount of phytohormones such as auxin, gibberellin and cytokinin were present in panchagavya (Table 1).

\section{Foliar application of panhagavya on growth parameters of Ocimum sanctum}

Panchagavya were sprayed as various percentage among that $8 \%$ of panchagavya have found to be the potential concentration in promoting growth in Ocimum sanctum as observed. The length of shoot and roots was gradually increased and found to be maximum at $8 \%$ of panchagavya. The maximum increase in shoot length was $104 \%$ and root length was $117 \%$ in panchagavya at $8 \%$ concentration and followed by $6 \%$ of panchagavya increased the shoot ant roots length was $63 \%$ and $103 \%$ in Ocimum sanctum against untreated plants. The total height of the plant was increased by $103 \%$ over control when treated with $8 \%$ and $6 \%$ of panchagavya showed total height as $87 \%$ but the remain percentage like $2 \%$ and $4 \%$ o panchagavya have acceptable values in shoot and roots length and also total height of the Ocimum sanctum plants compared with untreated plants. (Table. 2)

The application of panchagavya from 2\%/pot to $8 \% /$ pot seen gradually increased the fresh and dry weight of Ocimum sanctum plants. When Ocimum sanctum treated with panchagavya $(8 \%)$ was increased in fresh $237 \%$ and dry (246\%) weight of the seedlings over the control. Similarly considerable increase was seen in 6\%/pot of panchagavya in the fresh (136\%) and dry (175\%) weight respectively over control in Ocimum sanctum plants. The significant values were obtained when Ocimum sanctum plants were treated with $2 \%$ and $4 \%$ of panchagavya compared with control plants.

Leaves are the main organ in plants which absorb the nutrients quickly when given in the form of foliar spry. The leaf area of the panchagavya Ocimum sanctum plants was maximum increased at $8 \%$ of panchagavya and followed by other concentrations of panchagavya. 
Table.1 Elemental Composition and hormonal analyze of seaweed liquid extracts

\begin{tabular}{|l|l|}
\hline & Panchagavya g/llitre \\
\hline Physico chemical parameters & Yellowish green \\
\hline Colour & 4.3 \\
\hline Ph & \\
\hline Chemical parameters & $20.74 \pm 0.1546$ \\
\hline Boron (B) & $0.004 \pm 0.0004$ \\
\hline Sodium (Na) & 0 \\
\hline Magnesium (Mg) & $61.40 \pm 0.2594$ \\
\hline Aluminium (Al) & $\mathrm{NC}$ \\
\hline Potassium (K) & 0 \\
\hline Calcium (Ca) & 0 \\
\hline Chromium (Cr) & $0.95 \pm 0.026$ \\
\hline Manganese (Mn) & $0.99 \pm 0.061$ \\
\hline Iron (Fe) & 0 \\
\hline Nickel (Ni) & 0 \\
\hline Copper $(\mathrm{Cu})$ & 0 \\
\hline Zinc (Zn) & 0 \\
\hline Arsenic (As) & $0.039 \pm 0.006$ \\
\hline Selenium (Se) & 0 \\
\hline Molybdenum (Mo) & 0 \\
\hline Cadmium (Cd) & \\
\hline & \\
\hline Lead (Pb) & $2.35 \%$ \\
\hline Nitrogen (N) \% & $6.7 \mathrm{mg} / \mathrm{l}$ \\
\hline Growth hormones & $4.5 \mathrm{mg} / \mathrm{l}$ \\
\hline Auxin & $3.5 \mathrm{mg} / \mathrm{l}$ \\
\hline Cytokinin & \\
\hline Gibberellin & \\
\hline & \\
\hline
\end{tabular}

Table.2 Fertilizing efficiency of panchagavya on growth parameters of Ocimum sanctum

\begin{tabular}{|c|c|c|c|c|c|c|c|c|c|}
\hline S.No & Treatment & $\begin{array}{l}\text { Shoot } \\
\text { length } \\
\text { (cm) }\end{array}$ & $\begin{array}{l}\text { Root } \\
\text { length } \\
\text { (cm) }\end{array}$ & $\begin{array}{l}\text { Total } \\
\text { plant } \\
\text { height } \\
(\mathrm{cm})\end{array}$ & $\begin{array}{l}\text { Leaf } \\
\text { Area } \\
\left(\mathrm{cm}^{2}\right)\end{array}$ & $\begin{array}{l}\text { Number } \\
\text { of } \\
\text { leaves } \\
\text { (n) }\end{array}$ & $\begin{array}{l}\text { Number } \\
\text { of } \\
\text { branch } \\
\text { (n) }\end{array}$ & $\begin{array}{l}\text { Fresh } \\
\text { weight } \\
\text { (g) }\end{array}$ & $\begin{array}{l}\text { Dry } \\
\text { weight } \\
\text { (g) }\end{array}$ \\
\hline 1 & $\begin{array}{l}\text { Control } \\
\mathrm{T}_{1}\end{array}$ & $\begin{array}{l}28.93 \pm \\
0.4041\end{array}$ & $\begin{array}{l}7.06 \pm \\
0.4041\end{array}$ & $\begin{array}{l}32.03 \pm \\
0.4509\end{array}$ & $\begin{array}{l}7.5 \pm \\
0.3\end{array}$ & $\begin{array}{l}30.4 \pm \\
0.2\end{array}$ & $\begin{array}{l}4.1 \pm \\
0.4582\end{array}$ & $\begin{array}{l}5.01 \pm \\
0.11\end{array}$ & $\begin{array}{l}2.04 \pm \\
0.0636\end{array}$ \\
\hline 2 & $2 \% /$ pot $\mathrm{T}_{2}$ & $\begin{array}{l}34.43 \pm \\
0.5033 \\
117\end{array}$ & $\begin{array}{l}11.96 \pm \\
0.3511 \\
168\end{array}$ & $\begin{array}{l}46.4 \pm \\
0.4582 \\
143\end{array}$ & $\begin{array}{l}14.13 \pm \\
0.4163 \\
187\end{array}$ & $\begin{array}{l}46.1 \pm \\
0.5567 \\
167\end{array}$ & $\begin{array}{l}4.23 \pm \\
0.5859 \\
102\end{array}$ & $\begin{array}{l}5.89 \pm \\
0.4392 \\
121\end{array}$ & $\begin{array}{l}2.30 \pm \\
0.1026 \\
124\end{array}$ \\
\hline 3 & $4 \% /$ pot $\mathrm{T}_{3}$ & $\begin{array}{l}45.1 \pm \\
0.4582 \\
153\end{array}$ & $\begin{array}{l}13.03 \pm \\
0.3511 \\
183\end{array}$ & $\begin{array}{l}58.4 \pm \\
0.6 \\
181\end{array}$ & $\begin{array}{l}14.43 \pm \\
0.305 \\
191\end{array}$ & $\begin{array}{l}65.16 \pm \\
0.4725 \\
208\end{array}$ & $\begin{array}{l}10.06 \pm \\
0.4041 \\
244\end{array}$ & $\begin{array}{l}8.65 \pm \\
0.0793 \\
215\end{array}$ & $\begin{array}{l}3.25 \pm \\
0.0529 \\
216\end{array}$ \\
\hline 4 & $6 \% /$ pot $\mathrm{T}_{4}$ & $\begin{array}{l}46.11 \pm \\
0.45 \\
156\end{array}$ & $\begin{array}{l}14.4 \pm \\
0.4582 \\
203\end{array}$ & $\begin{array}{l}60.43 \pm \\
0.5033 \\
187\end{array}$ & $\begin{array}{l}18.16 \pm \\
0.6658 \\
241\end{array}$ & $\begin{array}{l}67.93 \pm \\
0.7023 \\
217\end{array}$ & $\begin{array}{l}10.96 \pm \\
0.4509 \\
266\end{array}$ & $\begin{array}{l}9.48 \pm \\
0.06 \\
236\end{array}$ & $\begin{array}{l}3.87 \pm \\
0.0568 \\
275\end{array}$ \\
\hline 5 & $8 \% /$ pot $\mathrm{T}_{5}$ & $\begin{array}{l}60.03 \pm \\
0.5507 \\
204\end{array}$ & $\begin{array}{l}15.43 \pm \\
0.2081 \\
217\end{array}$ & $\begin{array}{l}75.46 \pm \\
0.3 \\
203\end{array}$ & $\begin{array}{l}24.13 \pm \\
0.4163 \\
320\end{array}$ & $\begin{array}{l}84.13 \pm \\
0.5131 \\
269\end{array}$ & $\begin{array}{l}14.2 \pm \\
0.7 \\
345\end{array}$ & $\begin{array}{l}13.55 \pm \\
0.0655 \\
337\end{array}$ & $\begin{array}{l}4.31 \pm \\
0.03 \\
346\end{array}$ \\
\hline
\end{tabular}


Table.3 Fertilizing efficiency of panchagavya on biochemical parameters of Ocimum sanctum

\begin{tabular}{|c|c|c|c|c|c|c|c|}
\hline S. No & $\begin{array}{l}\text { Treatment } \\
\mathrm{s}\end{array}$ & $\begin{array}{l}\text { Starch } \\
\mathrm{mg} / \mathrm{g}\end{array}$ & $\begin{array}{l}\text { Glucose } \\
\mathrm{mg} / \mathrm{g}\end{array}$ & $\begin{array}{l}\text { Protein } \\
\mathrm{mg} / \mathrm{g}\end{array}$ & $\begin{array}{l}\text { Chlorophyll } \\
\text { a } \\
\mathrm{mg} / \mathrm{g}\end{array}$ & $\begin{array}{l}\text { Chlorophyll } \\
\text { b } \\
\mathrm{mg} / \mathrm{g}\end{array}$ & $\begin{array}{l}\text { Total } \\
\text { chlorophyll } \\
\text { mg/g }\end{array}$ \\
\hline 1 & $\begin{array}{l}\text { Control } \\
\mathrm{T}_{0}\end{array}$ & $37.6 \pm 1.24$ & $36.5 \pm 2.16$ & $37.3 \pm 1.24$ & $0.62 \pm 0.02$ & $0.88 \pm 0.02$ & $1.51 \pm 0.04$ \\
\hline 2 & $\begin{array}{l}2 \% / \text { pot } \\
\mathrm{T}_{1}\end{array}$ & $\begin{array}{l}43.3 \pm 1.24 \\
112\end{array}$ & $\begin{array}{l}47.3 \pm 0.94 \\
127\end{array}$ & $\begin{array}{l}39.3 \pm 1.24 \\
102\end{array}$ & $\begin{array}{l}1.14 \pm 0.01 \\
183\end{array}$ & $\begin{array}{l}1.59 \pm 0.01 \\
180\end{array}$ & $\begin{array}{l}2.75 \pm 0.03 \\
181\end{array}$ \\
\hline 3 & $\begin{array}{l}4 \% / \text { pot } \\
\mathrm{T}_{2}\end{array}$ & $\begin{array}{l}52.6 \pm 1.69 \\
136\end{array}$ & $\begin{array}{l}56.5 \pm 0.81 \\
152\end{array}$ & $\begin{array}{l}48.6 \pm 0.81 \\
126\end{array}$ & $\begin{array}{l}1.34 \pm 0.01 \\
215\end{array}$ & $\begin{array}{l}2.01 \pm 0.03 \\
228\end{array}$ & $\begin{array}{l}3.39 \pm 0.05 \\
223\end{array}$ \\
\hline 4 & $\begin{array}{l}6 \% / \text { pot } \\
\mathrm{T}_{3}\end{array}$ & $\begin{array}{l}69.6 \pm 1.24 \\
180\end{array}$ & $\begin{array}{l}60.6 \pm 2.05 \\
163\end{array}$ & $\begin{array}{l}69.3 \pm 1.24 \\
180\end{array}$ & $\begin{array}{l}1.46 \pm 0.03 \\
234\end{array}$ & $\begin{array}{l}2.19 \pm 0.05 \\
248\end{array}$ & $\begin{array}{l}3.68 \pm 0.08 \\
242\end{array}$ \\
\hline 5 & $\begin{array}{l}8 \% / \text { pot } \\
\mathrm{T}_{4}\end{array}$ & $\begin{array}{l}89.6 \pm 1.24 \\
232\end{array}$ & $\begin{array}{l}90.3 \pm 2.05 \\
243\end{array}$ & $\begin{array}{l}97.2 \pm 1.41 \\
252\end{array}$ & $\begin{array}{l}1.97 \pm 0.07 \\
315\end{array}$ & $\begin{array}{l}2.34 \pm 0.01 \\
265\end{array}$ & $\begin{array}{l}4.35 \pm 0.09 \\
286\end{array}$ \\
\hline
\end{tabular}

All the percentage of panchagavya increased the leaf area by $87-220 \%$. The leaf area was found to be maximum $(220 \%)$ when $8 \%$ of panchcgavya was given to Ocimum sanctum plants. $6 \%$ of panchagavya increased the leaf area to $141 \%$ more than untreated plants. The application of other concentrations as such $2 \%$ and $4 \%$ of panchagavya has also found to be significant increase values when compared with control plants. The number branch and leaves showed the maximum increase when applied $8 \%$ of panhagavya by $245 \%$ and $169 \%$ and $6 \%$ of panchagavya has also increased the number of branch and leaves as $166 \%$ and $117 \%$ with compared to untreated plants. The application of minimum concentrations of panchagavya such as $2 \%$ and $4 \% /$ pot has lighted significant increase values when compared with control plants. (Table. 2)

Foliar application of panchagavya on biochemical parameters of Ocimum sanctum

In case of biochemical constituents, the maximum increase of biochmicals were seen in $8 \%$ of panchagavya that was starch (132 $\%)$, glucose $(143 \%)$, protein $(152 \%)$, chlorophyll a (215\%), chlorophyll b (165\%) and total chlorophyll (186\%) compared to the untreated plant. The concentration of $6 \%$ of panchagavya $\left(T_{3}\right)$ enhanced the starch content, Glucose, Protein, Chlorophyll a, Chlorophyll b, Total Chlorophyll by $80 \%, 63$ $\%, 80 \%, 134 \%, 148 \%, 142 \%$ respectively. $2 \%$ and $4 \%$ concentration of panchagavya ( $\mathrm{T}_{1}$ and $\mathrm{T}_{2}$ ) enhanced the biochemical constituents but it was found to be lesser than T3 treatment. (Table 3).

Panchagavya is an organic formulation that enhances the biological efficiency of crop plants and quality of fruits and vegetables. Panchagavya is reported to contain biofertilizers like Azospirillum, Azotobactor, Phosphobacteria, Pseudomonas and Lactobacillus (Yadav and Lourduraj, 2006).

Perumal et al., (2006) reported that presence of growth regulatory substances such as Indole Acetic Acid (IAA), Gibberlic Acid (GA3), Cytokinin and essential plant nutrients from panchakavya caused a tremendous influence on the growth rate in Alium cepa. Papen et al., (2002) noted that the macro (N. $\mathrm{P}, \mathrm{K}$ and $\mathrm{Ca}$ ) and micro $(\mathrm{Zn}, \mathrm{Fe}, \mathrm{Cu}, \mathrm{Mn})$ nutrients besides total reducing sugars (glucose) prances in panchagavya and Chemolithotrops and autotropic nitrifiers (ammonifers and nitrifers) present in panchagavya which colonize in the leaves increased the ammonia uptake and enhance the total $\mathrm{N}$ supply. 
In our results, the growth parameters like shoot and root length, total plant height, leaf area, number of leaves, number of branch, fresh and dry weight similarly, biochemical parameters like starch, glucose, protein and chlorophyll content were increased when Ocimum sanctum plant treated with $8 \%$ of panchagavya. The obtained results are in agreement with the findings from the previous work done by Suchitra Rakesh et al., (2017) they said that the plant height $(18.24,68.35$ and $74.68 \mathrm{~cm})$, no. of leaves $(5,24$ and 28), fresh weight $(25.67,99.02$ and $99.69 \mathrm{mg})$ and dry weight $(9.60,26.12$ and $24.25 \mathrm{mg})$ at three different stage like seedling, flowering and yielding stage of Abelmoschus esculentus plant were observed in the treatment of $3 \%$ concentration of panchagavya.

The number of leaves (233.10) and leaf area (25.91) of Jasminum sambac were indicated that the Vermicompost @ 2.5 t/ha + Panchagavya@3 per cent foliar spray were good resulting candidate stated by Sendhilnathan et al., (2017). The treatment of panchagavya at $2.5 \%$ and neem oil $4 \mathrm{ml}$ per liter increased the chlorophyll content (4.15) in Capsicum sp (Mishra et al., 2015). The protein was enhanced by the application of $4 \%$ concentration of panchagavya (Gopal Lal Choudhary et al., 2017). The cow dung in panchagavya act as a medium for the growth of beneficial microbes and cow urine provides nitrogen which is essential for crop growth upon fermentation with other ingredients in panchagavya has beneficial effect on growth and yield (Patil et al., 2012). The $\mathrm{pH}$ of panchagavya was lowered to 4.52 at 30 days of fermentation and this might be due to Lactobacillus bacteria in panchagavya, which produced more organic acids during fermentation stated by Mathivanan et al., (2006). Further, the authors have reported the acetate, propionate and butyrate levels in panchagavya were ranged from 60.05 to $68.28,14.39$ to 17.79 and 6.40 to 7.65 percent, respectively, during the period from 10 to 40 days of fermentation. Lactobacillus count was increased from 8.62 at 10 days of fermentation to $8.71 \log 10 \mathrm{cfu} / \mathrm{g}$ at 30 days of fermentation. The total volatile fatty acids (TVFA) were higher at 30 days of fermentation. Panchagavya also known to contain biofertilizers such as Azospirillum, Azotobactor, Phosphobacteria and Pseudomonas were found besides Lactobacillus in Panchagavya (Yadav and Lourduraj, 2006). Besides these, growth regulatory substances such as Indole Acetic Acid (IAA), Gibberlic Acid (GA3), Cytokinin and essential plant nutrients from panchakavya (Perumal et al., 2006)) which caused a tremendous influence on the growth rate in Alium cepa and panchagavya at 30 days of age recorded better proposition of chemical and microbial composition favorable for utilization as a growth.

In our study, growth and biochemical parameters of Ocimum sanctum exhibited significant increase by all the panchagavya. Among the treatments, better results exhibited, $8 \%$ concentration o panchagavya showed positive results when compared to individual and control treatment. In general, magnesium and iron plays a pivotal role in synthesis of chlorophyll in the plant metabolism. Presence of magnesium and iron in seaweed extracts could have induced the metabolism involved in chlorophyll synthesis (Table 1). In addition, presence of growth hormones like IAA, cytokine, in panchagvya might also be responsible for enhancement in growth and physiology of Ocimum sanctum. Increase in growth and biochemical parameters on our experimental plant might be due to the cumulative action of the phytohormones and macro and micronutrients present in $8 \%$ of panchagvya (T4). Further studies are in underway to examine the optimal concentration and best combination of panchagavya on different medicinal plants. 


\section{References}

Aman Bhatia, Vishal Ahuja and Arvind Kumar Bhatt. 2016. Antimicrobial analysis of leaves extracts of Abies pindrow from Himachal Pradesh, Himalayan studies Journal (Special Issue). 1(1): 33-39

Anonymous. 2001. Monthly statistics of forest trade of India. GOI. Vol.1.

Arnon DI, 1949. Copper enzymes in isolated chloroplasts, polyphenol oxidase in Beta vulgaris. Plant Physiol 24: 1-15.

B'Hymer, Clayton, Judith A Brisbin, Karen L Sutton and Joseph A. Caruso. 2000. "New approaches for elemental speciation using plasma mass spectrometry." American Laboratory 32(3): 17-32.

Bremmer JM, 1960 "Determination of Nitrogen in Soil by the Kjeldahl Method," Journal of Agricultural Science 55(1):11-33.

Chandran R, Parimelazhagan T, Shanmugam S, Thankarajan S, \& Karuppusamy A. 2012. Antioxidant and antiinflammatory potential of Monochoria vaginalis: A wild edible plant. Journal of Food Biochemistry 36(4): 421-431.

Farmer BH. 1986. "Perspective on the "Green Revolution" in South Asia". Modern Asian Studies 20(01): 175-199.

Gopal Lal Choudhary, Sharma SK, Sanju Choudhary, Kendra Pal Singh, Kaushik MK and Bazaya BR. 2017. Effect of panchagavya on quality, nutrient content and nutrient uptake of organic Blackgram (Vigna mungo (L.) Hepper), Journal of Pharmacognosy and Phytochemistry 6(5): 1572-1575.

Gordon SA, Paleg LG. 1957. Quantitative measurement of indole acetic acid. Physiol. Plant 10: 37-48.

Graham HD, Henderson JHM, 1961. Reaction of gibberellic acid and gibberellins with Folin-Wu Phosphomolybdic acid reagent and its use for quantitative assay. Plant Physiol 36: 405-408.

Hazell PBR. 2009, The Asian Green Revolution, Intl Food Policy Res Inst 911: pp 31.

Khodaei Joghan A, Ghalavand A, Aghaalikhani M, Gholamhoseini $\mathrm{M}$ and Dolatabadian A. 2012. How organic and chemical nitrogen fertilizers, zeolite, and combinations influence wheat yield and grain mineral content. Journal of Crop Improvement 26: 116-129.

Lowry $\mathrm{OH}$, Rosebrough NJ, Farr AL, and Randell RJ. 1951. Protein measurement with Folin Phenol reagent. J. Biol. Chem 193: 265-275.

Mathivanan R, Edwin S C, Viswanathan K, Chandrasekaran D. 2006. Chemical, Microbial composition and antibacterial activity of modified panchagavya. International Journal of Cow Science, 2(2): (retrieved 12.02.10 from Indian Journals.com).

Mishra1 N, Sahu GS, Mishra P P and Ray M. 2015. Effect of Panchagavya on Growth and Yield of Capsicum, National Academy of Agricultural Science 33(4): 2613- 2616.

Nelson N. 1944. A photometric adaptation of Somogyis method for the determination of reducing sugar. Anal. Chem 31: 426428.

Papen H, GablerA, Zumbusch E and Rennenberg H. 2002. Chemo litho autotrophic nitrifiers in the phyllosphere of a Spruce ecosystem receiving high nitrogen input. Curr. Microbiol 44:5660.

Patil SV, Halikatti SI, Hiremath SM, Babalad HB, Sreenivasa MN, Hebsur NS, Somanagouda G. 2012. Effect of organics on growth and yield of chickpea (Cicer arietinum L.) in Vertisols. Karnataka Journal of Agriculture Science 25:326-331. 
Perumal K, Praveena K, Stalin V and Janarthanam B. 2006. Assessment of selected organic manures as plant growth hormones and their impact on the growth attributes of Alium cepa Lin. Current Science 8: 46-51.

Rajat Rashmi. 2002. Agro-techniques for Cultivation of some Homeopathic Medicinal Plants. Natural Product Radiance. Nov-Dec.

Rao M R, Palada M C and Becker B N. 2004. Medicinal and aromatic plants in agro forestry systems. Agrofor. Syst 61: 107122.

Rose R, Rose C L, Omi SK, Forry KR, Durall D $M$ and Bigg WL. 1991. Starch determination by perchloric acid vs enzymes: evaluating the accuracy and precision of six colorimetric methods. J. Agric. Food Chem 39: 2-11.

Saravi S S S, Shokrzadeh M. 2011. Role of pesticides in human life in the modern age: a review. In: Stoytcheva M (ed.) Pesticides in the modern world-risks and benefits. In- Tech; p 4-11.

Selvaraj N, Anita B, Saraswathi MG, 2006 in: Organic Hortiulture Creating a More Sustainable orming, (Horticulture
Research Station, TNAU, Udhagamandalam), 63.

Sendhilnathan R, Velmurugan V and Manimaran P. 2017. Effect of bio regulators along with organics on growth and yield of gundumalli (Jasminum sambac Ait), Journal of Pharmacognosy and Phytochemistry 6(5): 234-238.

Suchitra Rakesh, Poonguzhali S, Saranya B, Suguna S and Jothibasu K. 2017. Effect of Panchagavya on Growth and Yield of Abelmoschus esculentus cv. Arka Anamika, Int.J.Curr.Microbiol.App.Sci 6(9): 3090-3097.

Swaminathan C, Swaminathan V, Vijayalakshmi K. 2007. Panchagavya Boon to organicFarming, International Book, Distributing Co., Lucknow.

Syono K, Torrey JG, 1976. Identification of cytokinins of root nodules of the Garden Pea, Pisum sativum L. Plant Physiol 57: 602-606.

Yadav BK and Lourdraj CA. 2006. Effect of organic manures and Panchagavya spray on yield attributes and economics of rice (Oryza sativa). Crop Res 31: 1-5.

\section{How to cite this article:}

Veeranan Uthirapandi, Selvam Suriya, Ponnerulan Boomibalagan, Saminathan Eswaran, Subramanian Sivasangari Ramya, Narayanan Vijayanand and Durairaj Kathiresan. 2018. Organic Fertilizing Effect of Panchagavya on Growth and Biochemical Parameters of Holy Basil (Ocimum sanctum L.). Int.J.Curr.Microbiol.App.Sci. 7(06): 2637-2644. doi: https://doi.org/10.20546/ijcmas.2018.706.312 